\title{
Exploring the Host-Guest Interaction in Tourism Crisis Communication:
}

Biingjie Liu-Lastres $^{\mathrm{a} *}$ and Ignatius P. Cahyanto ${ }^{\mathrm{b}}$

${ }^{a}$ Department of Tourism, Event and Sport Management, Indiana University-Purdue

University Indianapolis; Indianapolis, USA; ${ }^{b}$ Department of Marketing and Hospitality,

University of Louisiana at Lafayette, Lafayette, USA.

\section{*Bingjie Liu-Lastres, Ph.D.}

Assistant Professor

Department of Tourism, Event, and Sport Management

School of Health and Human Sciences

Indiana University-Purdue University Indianapolis

bliulas@iu.edu

901 W New York St, Rm 250,

Indianapolis, IN46202

$+1317-278-3121$

This is the author's manuscript of the work published in final edited form as:

Liu-Lastres, B., \& Cahyanto, I. P. (2020). Exploring the host-Guest interaction in tourism crisis communication. Current Issues in Tourism, 1-13.

https://doi.org/10.1080/13683500.2020.1817876 


\title{
Exploring the Host-Guest Interaction in Tourism Crisis Communication
}

\begin{abstract}
The purpose of this paper was to explore the host-guest interaction in tourism crisis communication. Guided by a practice-based approach, our study used the recent event of the 2018 Florida Red Tide as the context and explored both visitors' and residents' information-acquiring and sharing practices in crisis communication. A total of 969 potential visitors and 460 Florida residents were surveyed, respectively. The findings show that visitors preferred residents as their primary information source. Repeat visitors who have no children and are the primary decision-maker are more likely to rely on residents for risk information than first-time visitors. The results further indicate that more than half of the resident sample have shared Red Tide information with visitors through various channels. Knowledge and social identity influenced their informationsharing behaviour. The findings suggest that residents can act as risk insiders in tourism crisis communication, A new research direction involving the guest-host interaction in tourism crisis management is proposed. The current sutdy offers practical implications for promoting effective risk and crisis communication in destinations and incorporating residents in tourism crisis communication and management.
\end{abstract}

Keywords: Guest-Host Interaction, Tourism Crisis Communication, Risk Insiders, Florida, Red Tide. 


\section{Introduction}

According to Molz (2012), we are now all connected in 'a mobile world crisscrossed by intersecting trajectories of people, media, data, goods, and risks' (p. 5). Tourism and travel is one of the primary vehicles that allow societies to become increasingly connected through encounters (Gössling, Cohen, \& Hibbert, 2018). Tourism encounters include 'hosts,' 'guests,' and their exchanges and interrelationships (King, 2015). It is believed that the quality and nature of these encounters can affect residents' perceptions of and support for tourism as well as visitors' destination experience and revisiting intentions (Bimonte \& Punzo, 2016; Su \& Wall, 2010). Accordingly, host-guest interaction has become an important research topic in tourism and has been examined in various contexts, such as ethnic tourism (Zhang, Xu, \& Xing, 2017), rural tourism (Kastenholz, Carneiro, Eusébio, \& Figueiredo, 2013) and the sharing economy (Sthapit \& Jiménez-Barreto, 2018).

Although the importance of understanding host-guest interactions in tourism is widely recognised, Mair, Ritchie, and Walters (2016) noticed a lack of studies exploring communication among stakeholders during tourism crises. Tourism crises are unexpected, adverse events that can generate devastating effects on areas heavily reliant on tourism (Ritchie, 2004). Crisis communication is at the heart of tourism crisis management and involves the exchange of risk and crisis information between key audiences (Pforr \& Hosie, 2008). Falkheimer and Heide (2006) referred to crisis communication as a 'sense-making process' (p. 180), suggesting that crisis communication assumes social meanings, which refers to a shared understanding among members of a social group (Røpke,2009). Within a tourism crisis communication context, both visitors and residents are critical recipients of risk and crisis information, and they interact with each other (Hajibaba, Karlsson, \& Dolnicar, 2017). For visitors, 
one of their most common practices in tourism crisis communication is to search and acquire information, as they rely on this to make informed decisions (Cahyanto \& Pennington-Gray, 2015; Sharifpour, Walter, Ritchie, \& Winter, 2014; Liu-Lastres, Schroeder, \& Pennington-Gray, 2018). For residents, they are more likely to undertake the role of information providers (Arsal, Woosnam, Baldwin, \& Backman, 2010; Liu \& Norman, 2016). These two populations and their behaviours are highly intertwined because most visitors tend to turn to residents for credible risk and crisis information (Cahyanto \& Pennington-Gray, 2015; Nierenberg et al., 2010). The interactions sometimes can evolve into connections and even bonding between visitors and residents (Hajibaba et al., 2017; Joo et al., 2018; Prebensen \& Foss, 2011).

Despite the complex nature of the dynamics between visitors and residents in tourism crisis communication, very few studies have explored this phenomenon indepth. A practice-based approach is well suited to this context. Practice theories are not unified theories, but rather, they provide a theoretical orientation that focuses on empirical facts and how people behave in different social settings (Nicolini, 2017). Jin, Moscardo, and Murphy (2019) suggested that a practice-based approach is useful in tourism studies, because it integrates both individual and social analysis, gives consideration to the contextual nature of tourism practices, and provides a critical lens to examine specific phenomena that emerge in tourism. Thus, the current study adopted a practice based approach to explore guest-host interactions in tourism crisis communication.

\section{Study Context}

One of the significant environmental crises that affected Florida in 2018 involved Red 
Tides, which are toxic algal blooms that occurred in the coastal areas of Mexico Gulf. The blooms can release toxins and be harmful to both the environment and human health. Although Red Tides are normally considered seasonal, the 2018 Red Tide has lasted since November 2017, becoming one of the most severe Red Tide events since 2006 (Resnick, 2018). According to Santana (2004), a tourism crisis can be defined as 'an occurrence which can threaten the normal operation and conduct of tourism-related business; damage a tourist destination's overall reputation for safety, attractiveness, and comfort by negatively affecting visitors' perception of that destination' (p. 307). The 2018 Florida Red Tide best exmplifies Santana's (2004) definition of a tourism crisis.

The occurrence of the 2018 Red Tides has led to several damages, including the death of manatees, dolphins, fish, and sea turtles, all of which are often washed along shores in ill-smelling masses (Resnick, 2018). The local tourism and hospitality industry was negatively impacted by the 2018 Florida Red Tide. Numerous beaches along Florida's Atlantic coast, such as Palm Beach and Haulover Beach, were all temporarily closed (Mitchell, 2018). The increasing concerns over Red Tides caused cancellations and declines in reservations among local hotels (Mitchell, 2018). The 2018 Red Tide business damage assessment report indicates that because of the Red Tides, 94 percent of businesses in Southwest Florida experienced financial losses, with 82 percent of them reporting losses over \$500,000 (Florida Division of Emergency Management, 2018).

Crisis communication is essential in this context, as useful crisis communication messages can aid destinations in combating tourism crises, negative destination images, and even stereotypes (Avraham \& Ketter, 2016; Mair et al., 2016). At an individual level, information exchange is the key to tourism crisis communication, because the 
most appropriate crisis and risk information can ally public safety concerns and shape travellers' future decisions and behaviours related to tourism and travel even during crises (Cahyanto \& Pennington-Gray, 2015; Sharifpour et al., 2014).

The current study used the 2018 Florida Red Tide as the context to examine the guest-host interaction in tourism crisis communication. Nicolini $(2017$, p. 31) suggests that a practice-based approach studies more than 'what is insight;' it aims at providing 'a better understanding of social phenomena by re-specifying in terms of practices and their associations.' A practice-based approach was employed in the current study, which examines the information-related behaviours of visitors and residents and explores if these two behaviours are related. Specifically, our study sought to (1) examine visitors' risk and crisis information-acquiring behaviour, investigate if they rely on residents for risk information, and identify the features of visitors who tend to rely on residents for Red Tide information, and (2) explore residents' information-sharing behaviour and the major drivers of their behaviour.

\section{Literature Review}

\section{Guest-Host Interactions in Tourism Crisis Communication}

As an essential part of tourism, guest-host interactions occur in various forms, such as when guests consume hospitality services, purchase on-site souvenirs, and visit ethnic attractions (Su \& Wall, 2010). Most tourism studies tend to view guest-host interactions in terms of resource exchanges between individuals, suggesting that residents offer visitors various hospitality products and services in return for financial gain (Bimonte \& Punzo, 2016). The social value of guest-host interactions is noteworthy. Sharpley (2014) remarked that tourism is about people 'interacting with other places and other people, undergoing experiences that may influence their own or the host community's attitudes, expectations, opinions and, ultimately, lifestyles'(pp. 1-2). 
Host-guest interactions occur in tourism crisis communication, where visitors undertake the role of information-acquirers, and residents act as information-providers. For visitors, information searching is one of their most common behaviours under uncertain situations, such as the onset of a tourism crisis. Viscusi (1995) contended that individuals make choices under the uncertainty of threats by maximising the expected utilities of available options. In a similar fashion, with the outbreak of a crisis, visitors naturally rely on searched and collected information to assess the situation and select the best possible option to protect themselves (Sharifpour et al., 2014). Visitors tend to perceive the information provided by local residents as authentic, truthful, and trustworthy, especially in crisis times (Arsal et al., 2010; Cahyanto \& Pennington-Gray, 2015). Despite visitors' increasing dependence on residents for accurate crisis and risk information, very few studies have explored their practice in-depth and outlined what type of visitors are more likely to depend on residents.

Unlike visitors, residents are generally familiar with the local environment and are aware of the situation and surrounding resources. Residents have more knowledge of emerging issues at a destination (Nierenberg et al., 2010). Thus, residents are often considered reliable information sources during crises (Cahyanto \& Pennington-Gray, 2015). Offering risk information to incoming visitors aims at helping or benefiting visitors and, as such, is a pro-social behaviour (Dovidio, Pillavin, Shroeder, \& Penner, 2017). Encouraging residents' pro-social behaviour can help enhance a destination's friendliness (Liu \& Norman, 2015; Tung, 2019), and buttress a destination's efforts in managing a crisis (Rodríguez, Trainor, \& Quarantelli, 2006). Shove, Pantzar, and Watson (2012) emphasize the importance of understanding the drivers of people's prosocial behaviour because their decisions reflect their beliefs, values, and lifestyles. 
Social Identity Theory has been frequently used to explain residents' pro-social behaviour towards visitors (Liu \& Norman, 2015). Stets and Biga (2003) defined identity as 'a set of meanings attached to the self that serves as a standard or reference that guides behaviour in situations' (p. 401). By categorising oneself into social groups, individuals foster a sense of belonging, generate emotional attachment, and practice positive activities representing the group (Dholakia, Bagozzi, \& Pearo, 2004). The concept of identity stresses the importance of similarity shared with members of the same group and differences from others (Dholakia et al., 2004). One's social identity can be established using various criteria, such as memberships, religious affiliation, gender, and even residency (Palmer et al., 2013). As Nunkoo and Gursoy (2012) concluded, Social Identity Theory can be used to examine the vital connection between individuals and social structures such as the host community. Therefore, it can offer a useful theoretical framework to explore residents' attitudes and behaviours concerning tourism.

\section{A Practice-Based Approach in Tourism}

Practice theories, also known as social practice theories, are not a unified body of theory. Instead, they consist of multiple theoretical positions that all address a similar empirical orientation in social research (Reckwitz, 2002; Schatzki, 1997; Warde, 2005). Many scholars have contributed to the development of practice theories, including philosophers such as Heidegger and Wittgenstein, and sociologists such as Giddens (1976), Bourdieu (1976), Reckwitz (2002), Shatzki (1997), Warde (2005), and Shove et al. (2012). Instead of focusing on either individuals or social structures, the scope of practice theories concentrates mainly on practice, which is a middle level between agency and structure and has been treated as the core unit of analysis in practice-based 
studies.

Nicolini (2017) defined practices as 'a real-time doing and saying something in a specific place and time (p. 219)'. Practices are carried out by people in different social settings, but they are driven by the same or similar rituals, material objects, understanding, motivation, and expectations (Reckiwitz, 2002). Thus, an essential step in behavioural studies is to recognise and reconfigure practices (Luzecka, 2016). Beyond such a loosing agreement, Schatzki (2001) pointed out that, 'there is no unified practice approach (p.2).' Some researchers (e.g., Reckwiz, 2002; Shove \& Pantzar, 2005) followed the traditional approach, examining the key constructs of the theory (i.e., materials, settings, meanings), while others (e.g., Warde, 2005; Shove et al., 2012) adopted a holistic approach and treated practice theory as a grand theory, analysing individual practices as well as co-evolving practices, the linkages between practices, and how practices represent the bridges between people and the broader social setting.

De Souza Bispo (2016) first elaborated on the concept of 'tourism as practice.' Lamers, Van der Duim, and Spaargaren (2017) further illustrated how practice theories could be used in tourism studies, whereby social practices are the starting point and focus for theorising and conducting research in tourism and travel. Although relevant, the application of practice theories in tourism remains nascent. Some studies have applied practice theories to the tourism context by breaking down the concept of practice into different constructs. For example, Jin et al. (2019) investigated Chinese outbound tourists' shopping behaviour in Australia. They explored how the key constructs, such as meanings, competence, materials, and settings, were reflected in a tourism setting. Most studies, however, tend to adopt a grand theory approach and apply practice theories as an overall framework with empirical orientations. For instance, Luzecka (2016) analysed the phenomena of gap year travel using a practice-based 
approach and revealed the influences of social elements on people's gap-year travel

decisions. Similarly, Dolan, Seo, and Kemper (2019) used a practice-based approach to analyse tourist complaining behaviours on social media.

Our study relied on a practice-based approach, which features the ontological nature and sees practices as the reflection of social interactions and social meanings within a given context (Dolan et al., 2019). Schatzki (2001) argued that social phenomena are represented by bundles of practices. Practices can be related to each other, as sometimes one practice relies on another as an outcome or a resource (Nickoni, 2017). When it comes to the current context, our study focused on visitors' informationsearching behaviour and residents' information-sharing behaviour. We noted that these two practices could be related because visitors' preference for and reliance on local sources for credible information would lead to the need to understanding residents' information-sharing behaviour. As such, by using a practice-based approach, the current study is holistic in nature and emphasises on the analysis of practices from two populations and the potential linkages between them.

\section{Methods}

\section{Research Design}

The overall goal of our study is to explore the dynamics between residents and visitors in tourism crisis communication, using Florida Red Tide as the context. Guided by a practice theory-based approach, the current study conducted two surveys (Figure 1). The visitor survey examined potential visitors' information-acquiring behaviour during Red Tide and if they relied on residents as information resources. Their reliance on residents was an essential linkage connecting visitors and residents in tourism crisis communication. The resident survey investigated residents' risk-information sharing 
behaviour and identified the major drivers of their information-sharing behaviour. Social Identity theory was also used here to provide additional explanation on the influence of social elements.

\section{[Insert Figure 1 Here]}

\section{Visitor Study}

Measurements. Data from 969 adult American travellers were collected through a paid online panel in December 2018. The criteria for participants were that they must (1) be non-Florida residents, and (2) have a plan to visit Florida in the next six months. Each participant was provided with financial compensation. Firstly, information related to individual characteristics, such as demographic information (e.g., age, gender, education level, household income, marital status, and the number of children) and past travel experience was collected. Secondly, to measure respondents' knowledge of Red Tide, they were asked (1) if they have heard of Red Tide, and (2) how confident were they in explaining Red Tide and the effects to their friends and family. Lastly, to explore potential visitors' information-acquiring behaviour, the participants were asked to indicate (1) if they would look for Red Tide information in Florida for their upcoming trip ( $1=$ Yes, $2=$ No), and (2) if they would prefer residents as the source of information $(1=$ Yes, $2=$ No).

Data Analysis. To analyse the data, the statistical package for social sciences (IBM SPSS 24) software was used. Descriptive analyses were run to report the characteristics of the sample. To examine visitors' information-acquiring behaviour and their reliance on residents, the sample was asked (1) if they would search any Red Tide information for their incoming trip to Florida and (2) if they would turn to residents for the information. Based on the answer to these two questions, the visitor sample was 
divided into three groups : (1) non-information seekers who would not search any Red Tide information for their incoming trips to Florida; (2) regular information seekers who would search Red Tide information but would not use residents as the information source; (3) resident-reliant risk information seekers who would search Red Tide information for their trips and would turn to residents for the information. A series of ANOVA/chi-square tests were used to compare the differences between groups.

\section{Resident Study}

Measurements. Data from 461 Florida residents was collected through a paid online panel in December 2018. Participants were adults who currently reside in Florida and were provided with financial compensation for completing the survey. Firstly, information related to individual characteristics, such as demographic information (e.g., age, gender, education level, household income, marital status, and number of children) and length of residence was collected. Secondly, to measure respondents' knowledge related to Red Tide, they were asked (1) if they have heard of Red Tide, and (2) how confident were they in explaining Red Tide and the effects to their friends and family. Thirdly, to examine respondents' information-sharing behaviour, they were asked two questions: (1) have they ever shared information with visitors regarding Red Tide in Florida on a binary scale where " $1=$ Yes" and " $2=$ No" and (2) through what ways they shared the information. Lastly, respondents' social identity as a Florida resident was measured using an existing scale consisting of six items (i.e., Dholakia et al., 2014; Liu \& Norman, 2015). The Cronbach's alpha value is above an acceptance level of .7, suggesting that the scale is reliable (Cronbach's alpha $=.91, \mathrm{M}=3.94, \mathrm{SD}=$ $.94)$. 
Data Analysis. To analyse the data, the statistical package for social sciences (IBM SPSS 24) software was used. Descriptive analyses were run to report the characteristics of the sample. Logistic regression analyses were conducted to identify major drivers of residents' information-sharing behaviour. The sample's informationsharing behaviour was entered as the dependent variable ( $1=$ have shared information; $0=$ have not shared information). Demographic variables (e.g., age, gender, length of residency), knowledge, and social identity were treated as independent variables.

\section{Results}

\section{Sample Characteristics}

As shown in Table 1, the visitor sample comprises 969 responses. Half of the participants (50\%) were 25-34 years old. Approximately half of the participants were male (54\%) and had a bachelor's degree (49\%). Most of them were married (58\%) and had children (51\%). Only a few participants (9\%) had never been to Florida. Additionally, the resident sample comprises 461 responses. About one-third (38\%) of the respondents were 25-34 years old. Half of them (54\%) were female, and around one-third (34\%) had a bachelor's degree. Some of them (41\%) were married, and the majority $(60.7 \%)$ had no children. Most of the participants (74\%) lived in Florida for more than ten years.

\section{[Insert Table 1 Here]}

Visitors' Risk and Crisis Information-Acquiring Behaviour

The first objective of this research was to examine visitors' general risk and crisis information-acquiring behaviour and their reliance on residents for information. The majority ( $86 \%)$ of the visitor sample indicated that they would seek Red Tide 
information for their upcoming trip to Florida. Around three-tenths of the sample (32\%) prefer locals for the information. Based on the information-acquiring behaviour and their information source preferences, the visitor sample was further divided into three groups: (1) non-information seekers (14\%), (2) regular information seekers (54\%) who would like to search for information but normally would not turn to residents and (3) information seekers who prefer residents as the source (32\%). As shown in Table 2, the differences between groups mainly lie in age $\left(\chi^{2}=27.55 ; p=.01\right)$, gender $\left(\chi^{2}=6.42\right.$; $\mathrm{p}=.04)$, marital status $\left(\chi^{2}=10.70 ; \mathrm{p}=.03\right)$, number of children $\left(\chi^{2}=11.08 ; \mathrm{p}=.03\right)$, knowledge $\left(\chi^{2}=17.66 ; \mathrm{p}<.01\right)$, the role in travel decision making $\left(\chi^{2}=18.58 ; \mathrm{p}=.02\right)$, and past travel experiences $\left(\chi^{2}=10.62, \mathrm{p}=.03\right)$. A closer examination reveals that people who are in the resident-reliant information group are more likely to be in the age groups of 35-49 and 50-65, have no children, are the primary decision-maker, and have been to Florida in the past.

\section{Residents' Risk and Crisis Information-Sharing Behaviour}

The second focus of the current resaerch was on residents' information-sharing behaviour as well as the major drivers of the behaviour. More than half of the sample $(56 \%)$ have shared risk and crisis information with visitors regarding the 2018 Red Tide event in Florida. The most common way risk information was shared was through word-of-mouth (77\%), forwarding related information on social media $(30 \%)$ and actively posting information on their own social media pages (27\%). Additionally, the results of the logistic regression analyses (Table 2 ) showed that the model was statistically significant $(\chi 2(\mathrm{df}=11, \mathrm{~N}=460)=167.64, \mathrm{p}<.01)$ and was able to explain between $31 \%($ Cox \& Snell $\left.\mathrm{R}^{2}=.31\right)$ to $41 \%\left(\right.$ Nagelkerke $\left.\mathrm{R}^{2}=.41\right)$ of the variance in the sample's informationsharing behaviour. Interestingly, knowledge $(\beta=.40, p<.01)$ and social identity $(\beta=.26, p$ $=.04$ ) were significant predictors of the dependent variable. 
[Insert Table 2 Here]

\section{Discussion}

The current study used a practice-based approach to explore the host-guest interaction in tourism crisis communication. The study context mainly concerns the outbreak of 2018 Florida Red Tide. The primary findings of our study confirmed that visitors and residents are interrelated in the tourism crisis communication process. Their connection is manifested through visitors' preference of locals as information providers and residents' information-sharing behavior.

The connections between visitors' information-searching and residents' informationsharing behavior are consistent with the scope of pratice theories, which prioritise the practices as well as the links between them (Shove et al., 2012). The findings provide support to applying a pratice-based approach in tourism studies as well as highlight the significance of further exploring guest-host interactions in different contexts including tourism crisis communication.

Shove et al. (2012) addressed the importance of analysing the links between practices, because 'practices emerge, persist, and disappear as links between their defining elements are made and broken'(p. 23).

Tourism studies suggest (e.g., Cahyanto \& Pennington-Gray, 2015; Liu \& Norman, 2015) that both visitors' information-searching behaviour and residents' information-sharing behaviour have become more and more common. Our study find 
that these two behaviours are linked because some visitors do rely on residents for risk information, and many residents have already shared the information through various channels, both online and in-person. Establishing this link between these two activities offers a fresh perspective to examine guest-host interaction in tourism crisis communication, as well as underlines the necessity of using a holistic approach in tourism research.

The starting point for our study lies in an exploration of visitors' informationacquiring behaviour. The findings reinforced the idea that the need to be connected to locals is more prominent among repeat visitors who hold decision-making power for vacation plans. Previous tourism literature suggest that repeat visitors tend to be socially focused, and eager to establish connections with the destination (Fakeye \& Crompton, 1991; Lau \& Mckercher, 2004; Prayag \& Ryan, 2012). Repeat visitors’ increasing reliance on residents can be attributed to their desire to stay socially relevant and form a social tie with the local community. As suggested by the practice theories, social values are embedded in people's activities, and their behaviors always mean 'something' (Nicolimi, 2007). Our interpretation of visitors' information searching behavior should move beyond the superficial value; instead, more attention should be devoted to its underlying meanings and social significance.

\section{References}


Arsal, I., Woosnam, K. M., Baldwin, E. D., \& Backman, S. J. (2010). Residents as travel destination information providers: An online community perspective. Journal of Travel Research, 49(4), 400-413.

Avraham, E., \& Ketter, E. (2016). Tourism marketing for destinations with negative images. In Tourism Marketing for Developing Countries (pp. 67-82). Palgrave Macmillan.

Bimonte, S., \& Punzo, L. F. (2016). Tourist development and host-guest interaction: An economic exchange theory. Annals of Tourism Research, 58, 128-139.

Bourdieu, P. (1976). Outline of a theory of practice. Translated by R. Nice. Cambridge University Press

Cahyanto, I., \& Pennington-Gray, L. (2015). Communicating hurricane evacuation to tourists: Gender, past experience with hurricanes and place of residence. Journal of Travel Research, 54(3), 329-343.

de Souza Bispo, M. (2016). Tourism as practice. Annals of Tourism Research, 61, 170179.

Dholakia, U. M., Bagozzi, R. P., \& Pearo, L. K. (2004). A social influence model of consumer participation in network-and small-group-based virtual communities. International Journal of Research in Marketing, 21(3), 241-263.

Dolan, R., Seo, Y., \& Kemper, J. (2019). Complaining practices on social media in tourism: A value co-creation and co-destruction perspective. Tourism Management, 73, 35-45.

Dovidio, J. F., Piliavin, J. A., Schroeder, D. A., \& Penner, L. A. (2017). The social psychology of prosocial behavior. Psychology Press.

Eagly, A. H. (2009). The his and hers of prosocial behavior: An examination of the social psychology of gender. American Psychologist, 64(8), 644. 
Falkheimer, J., \& Heide, M. (2006). Multicultural crisis communication: Towards a social constructionist perspective. Journal of Contingencies and Crisis Management, 14(4), 180-189.

Faulkner, B., \& Vikulov, S. (2001). Katherine, washed out one day, back on track the next: A post mortem of a tourism disaster. Tourism Management, 22, 331-344

Fakeye, P. C., \& Crompton, J. L. (1991). Image differences between prospective, firsttime, and repeat visitors to the Lower Rio Grande Valley. Journal of Travel Research, 30(2), 10-16.

Florida Division of Emergency Management (2018). ESF-18 Business damage assessment statewide summary report. Southwest Florida Red Tide. Florida Division of Emergency Management.

Gössling, S., Cohen, S. A., \& Hibbert, J. F. (2018). Tourism as connectedness. Current Issues in Tourism, 21(14), 1586-1600.

Giddens, A. (1976). New rules of sociological method. Hutchinson.

Hajibaba, H., Karlsson, L., \& Dolnicar, S. (2017). Residents open their homes to tourists when disaster strikes. Journal of Travel Research, 56(8), 1065-1078.

Hardy F.J., Bouchard, D., Burghdoff, M., Hanowell, R., LeDoux, B., Preece, E., Tuttle, L., \& Williams, G. (2016). Education and notification approaches for harmful algal blooms (HABs), Washington State, USA. Harmful Algae, 60, 70-80.

Jin, H., Moscardo, G., \& Murphy, L. (2019). Exploring Chinese Outbound Tourist Shopping: A Social Practice Framework. Journal of Travel Research, DOI:0047287519826303.

Joo, D., Tasci, A. D., Woosnam, K. M., Maruyama, N. U., Hollas, C. R., \& Aleshinloye, K. D. (2018). Residents' attitude towards domestic tourists 
explained by contact, emotional solidarity and social distance. Tourism Management, 64, 245-257.

Kastenholz, E., Carneiro, M. J., Eusébio, C., \& Figueiredo, E. (2013). Host-guest relationships in rural tourism: Evidence from two Portuguese villages. Anatolia, 24(3), 367-380.

King, V. T. (2015). Encounters and mobilities: Conceptual issues in tourism studies in Southeast Asia. SOJOURN: Journal of Social Issues in Southeast Asia, 30(2), 497-527.

Lamers, M., Van der Duim, R., \& Spaargaren, G. (2017). The relevance of practice theories for tourism research. Annals of Tourism Research, 62, 54-63.

Lau, A. L., \& McKercher, B. (2004). Exploration versus acquisition: A comparison of first-time and repeat visitors. Journal of Travel Research, 42(3), 279-285.

Liu, B. \& Norman, W., (2015). Developing a conceptual framework to understand local residents' contribution in online travel communities. International Journal of Tourism Anthropology, 4(4), 367-382.

Liu-Lastres, B., Schroeder, A., \& Pennington-Gray, L. (2018). Cruise line customers' responses to risk and crisis communication messages: An application of the risk perception attitude framework. Journal of Travel Research, 58(5), 849 - 865.

Luzecka, P. (2016). “Take a gap year!” A social practice perspective on air travel and potential transitions towards sustainable tourism mobility. Journal of Sustainable Tourism, 24(3), 446-462.

Mair, J., Ritchie, B. W., \& Walters, G. (2016). Towards a research agenda for postdisaster and post-crisis recovery strategies for tourist destinations: A narrative review. Current Issues in Tourism, 19(1), 1-26. 
Mansfeld, Y. (2006). The role of security information in tourism crisis management: the missing link. In Mansfeld \& Pizam (Eds). Tourism, security \& safety: From theory to practice (pp. 271-290). Routledge.

Mitchell, C. (2018, Sept 4). Worst red tide outbreak in decades hurts Florida's economy, tourism. Retrieved from https://www.accuweather.com/en/weathernews/worst-red-tide-outbreak-in-decades-hurts-floridas-economytourism/70005939

Molz, J. G. (2012). Travel connections: Tourism, technology, and togetherness in a mobile world. Routledge: New York City.

Nicolini, D. (2017). Practice theory as a package of theory, method and vocabulary: Affordances and limitations. In Methodological reflections on practice oriented theories (pp. 19-34). Springer, Cham.

Nierenberg, K., Byrne, M. M., Fleming, L. E., Stephan, W., Reich, A., Backer, L. C., \& Kirkpatrick, B. (2010). Florida red tide perception: Residents versus tourists. Harmful Algae, 9(6), 600-606.

Nunkoo, R. \& Gursoy, D. (2012). Residents' support for tourism. An Identity Perspective. Annals of Tourism Research, 39. 243-268.

Palmer, A., Koenig-Lewis, N., \& Jones, L. E. M. (2013). The effects of residents' social identity and involvement on their advocacy of incoming tourism. Tourism Management, 38, 142-151.

Pforr, C., \& Hosie, P. J. (2008). Crisis management in tourism: Preparing for recovery. Journal of Travel \& Tourism Marketing, 23(2-4), 249-264.

Prayag, G. \& Ryan, C. (2012). Antecedents of Tourists' Loyalty to Mauritius The Role and Influence of Destination Image, Place Attachment, Personal Involvement, and Satisfaction. Journal of Travel Research, 51. 342-356. 
Prebensen, N. K., \& Foss, L. (2011). Coping and co-creating in tourist experiences. International Journal of Tourism Research, 13(1), 54-67.

Reckwitz, A. (2002). Toward a theory of social practices: A development in culturalist theorising. European Journal of Social Theory, 5(2), 243-263.

Resnick, B. (2018, October 8). Why Florida's red tide is killing fish, manatees, and turtles. Retrieved from https://www.vox.com/energy-andenvironment/2018/8/30/17795892/red-tide-2018-florida-gulf-sarasota-sanibelokeechobee

Ritchie, B. W. (2004). Chaos, crises, and disasters: a strategic approach to crisis management in the tourism industry. Tourism Management, 25(6), 669-683.

Rittichainuwat, B. N. (2008). Responding to disaster: Thai and Scandinavian tourists' motivation to visit Phuket, Thailand. Journal of Travel Research, 46(May), 422432.

Rodriguez, H., Trainor, J., \& Quarantelli, E. L. (2006). Rising to the challenges of a catastrophe: The emergent and prosocial behavior following Hurricane Katrina. The Annals of the American Academy of Political and Social Science, 604(1), $82-101$.

Røpke, I. (2009). Theories of practice-New inspiration for ecological economic studies on consumption. Ecological Economics, 68(10), 2490-2497.

Santana, G. (2004). Crisis management and tourism: Beyond the rhetoric. Journal of Travel \& Tourism Marketing, 15(4), 299-321.

Schatzki, T. R. (1997). Practices and actions a Wittgensteinian critique of Bourdieu and Giddens. Philosophy of the Social Sciences, 27(3), 283-308.

Schatzki, T. (2001), "Introduction: practice theory”, in Schatzki, T., Knorr Cetina, K. and von Savigny, E. (Eds), The practice turn in contemporary theory. Routledge. 
Sharifpour, M., Walter, G., Ritchie, B., \& Winter, C. (2014). Investigating the role of prior knowledge in tourist decision making: A Structural Equation Model of risk perceptions and information search. Journal of Travel Research. 53(3). 307-322.

Sharpley, R. (2014). Host perceptions of tourism: A review of the research. Tourism Management, 42, 37-49.

Shove, E., \& Pantzar, M. (2005). Consumers, producers and practices: Understanding the invention and reinvention of Nordic walking. Journal of Consumer Culture 5, 43-64

Shove, E., Pantzar, M., \& Watson, M. (2012). The dynamics of social practice: Everyday life and how it changes. Sage.

Stets, J. E., \& Biga, C. F. (2003). Bringing identity theory into environmental sociology. Sociological Theory, 21(4), 398-423.

Sthapit, E., \& Jiménez-Barreto, J. (2018). Sharing in the host-guest relationship: perspectives on the Airbnb hospitality experience. Anatolia, 29(2), 282-284.

Su, M. M., \& Wall, G. (2010). Implications of host-guest interactions for tourists' travel behavior and experiences. Turizam: međunarodni znanstveno-stručni časopis, 58(1), 37-50.

Tung, V. W. S. (2019). Helping a lost tourist: The effects of metastereotypes on resident prosocial behaviors. Journal of Travel Research, 58(5), 837-848.

Viscusi, W. (1995). Fatal tradeoffs: Public and private responsibilities for risk. Oxford University Press.

Warde, A. (2005). Consumption and theories of practice. Journal of Consumer Culture, 5(2), 131-153.

Zhang, J., Xu, H. G., \& Xing, W. (2017). The host-guest interactions in ethnic tourism, Lijiang, China. Current Issues in Tourism, 20(7), 724-739. 
Figure 1. Research Design 


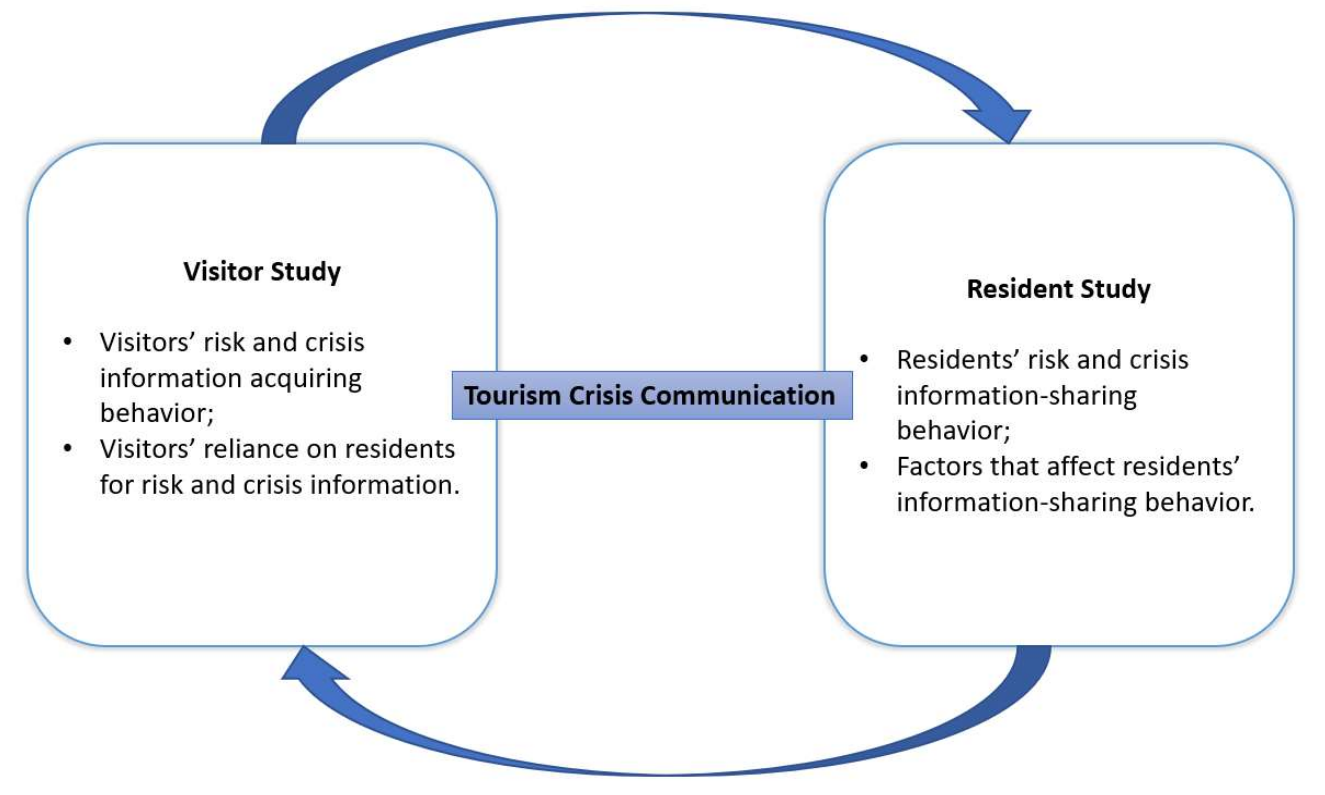


Table 1. Sample Characteristics

\begin{tabular}{|c|c|c|c|c|}
\hline \multirow[b]{3}{*}{ Variable } & \multicolumn{2}{|c|}{ Visitor Study } & \multicolumn{2}{|c|}{ Resident Study } \\
\hline & \multicolumn{2}{|c|}{$N=969$} & \multicolumn{2}{|c|}{$N=461$} \\
\hline & Frequency & Valid \% & Frequency & Valid \% \\
\hline \multicolumn{5}{|l|}{ Age } \\
\hline $18-24$ & 64 & 6.6 & 54 & 11.8 \\
\hline $25-34$ & 480 & 49.5 & 171 & 37.5 \\
\hline $35-49$ & 304 & 31.4 & 127 & 27.9 \\
\hline $50-64$ & 100 & 10.3 & 84 & 18.4 \\
\hline 65 or older & 21 & 2.2 & 20 & 4.4 \\
\hline \multicolumn{5}{|l|}{ Gender } \\
\hline Male & 518 & 53.5 & 210 & 46.1 \\
\hline Female & 451 & 46.5 & 246 & 53.9 \\
\hline \multicolumn{5}{|l|}{ Education } \\
\hline Less than a high school & 1 & .1 & 1 & .2 \\
\hline \multicolumn{5}{|l|}{ degree } \\
\hline High school graduate & 67 & 6.9 & 40 & 8.8 \\
\hline Some college but no degree & 148 & 15.3 & 120 & 26.3 \\
\hline Associate degree & 94 & 9.7 & 76 & 16.7 \\
\hline Bachelor's degree & 471 & 48.6 & 154 & 33.8 \\
\hline Master's degree & 146 & 15.1 & 51 & 11.2 \\
\hline Doctoral degree & 15 & 1.5 & 3 & .7 \\
\hline Professional degree & 27 & 2.8 & 11 & 2.4 \\
\hline
\end{tabular}




\begin{tabular}{|c|c|c|c|c|}
\hline \multicolumn{5}{|l|}{ Marital Status } \\
\hline Married & 561 & 57.9 & 186 & 40.8 \\
\hline Widowed & 10 & 1.0 & 8 & 1.8 \\
\hline Divorced & 51 & 5.3 & 52 & 11.4 \\
\hline Separated & 20 & 2.1 & 10 & 2.2 \\
\hline Never Married & 327 & 33.7 & 200 & 43.9 \\
\hline \multicolumn{5}{|c|}{ Number of Children } \\
\hline 0 & 478 & 49.3 & 277 & 60.7 \\
\hline 1 & 198 & 20.4 & 83 & 18.2 \\
\hline 2 & 193 & 19.9 & 60 & 13.2 \\
\hline 3 or more & 100 & 10.3 & 36 & 7.8 \\
\hline \multicolumn{5}{|c|}{ Have heard of the Red Tide event in Florida } \\
\hline Yes & 511 & 52.7 & 412 & 90.4 \\
\hline No & 458 & 47.3 & 44 & 9.6 \\
\hline
\end{tabular}


Table 2. Regression Analyses Results

\begin{tabular}{|c|c|c|c|}
\hline & \multicolumn{3}{|c|}{ DV: The probability of information-sharing } \\
\hline Variable & $\beta$ & Wald & Sig \\
\hline AGE & & 7.98 & .09 \\
\hline $18-24$ & -.99 & 2.16 & .15 \\
\hline $25-34$ & -1.00 & 2.68 & .10 \\
\hline $35-49$ & -1.51 & 5.77 & $.02 *$ \\
\hline $50-64$ & -.81 & 1.60 & .21 \\
\hline \multicolumn{4}{|l|}{65 and above } \\
\hline \multicolumn{4}{|l|}{ GENDER } \\
\hline Male & -.33 & .232 & .16 \\
\hline \multicolumn{4}{|l|}{ Female } \\
\hline LENGTH OF RESIDENCY & & 1.39 & .50 \\
\hline Up to 3 years & .46 & 1.12 & .29 \\
\hline $4-10$ years & .21 & .47 & .49 \\
\hline \multicolumn{4}{|l|}{ More than 10 years } \\
\hline NUMBER OF CHILDREN & & .05 & .98 \\
\hline \multicolumn{4}{|l|}{ No children } \\
\hline 1 child & -.03 & .31 & .92 \\
\hline 2 or more children & -.08 & .05 & .93 \\
\hline \multicolumn{4}{|l|}{ SUBJECTIVE KNOWLEDGE } \\
\hline Have heard of Red tide in FL & -2.63 & 15.04 & $<.01 * *$ \\
\hline Confidence in explaining & .40 & 70.64 & $<.01 * *$ \\
\hline
\end{tabular}


SOCIAL IDENTITY

Social identity as a FL

.26

4.21

$.04^{*}$

resident

Model Statistics

$\chi^{2}(12.460)=167.64, \mathrm{p}<.01$, Cox \& Snell $R^{2}=.31$,

Nagelkerke $R^{2}=.41$.

Note" ${ }^{*} p<.05 .{ }^{* *} p<.01$ 